\title{
Report on Intern Rights Advocacy in 2013-2014
}

\author{
Intern Labor Rights
}

New York City, USA, internlaborrights.com

Abstract: 2013-2014 was a milestone for intern rights, with significant accomplishments in the fight to have interns recognized as employees with rights to both pay and workplace protections. This article reviews activist efforts to bring an end to the precarious position of unpaid and underpaid interns in the United States, from the work of the advocacy group Intern Labor Rights and other organizations, to efforts on the judicial and legislative levels. We highlight the movement's accomplishments in 2013-14 and look forward to the goals it hopes to attain in the near future, all the while contextualizing this issue within the larger framework of national labour and wage movements.

Keywords: interns, internships, activism, wages, labour

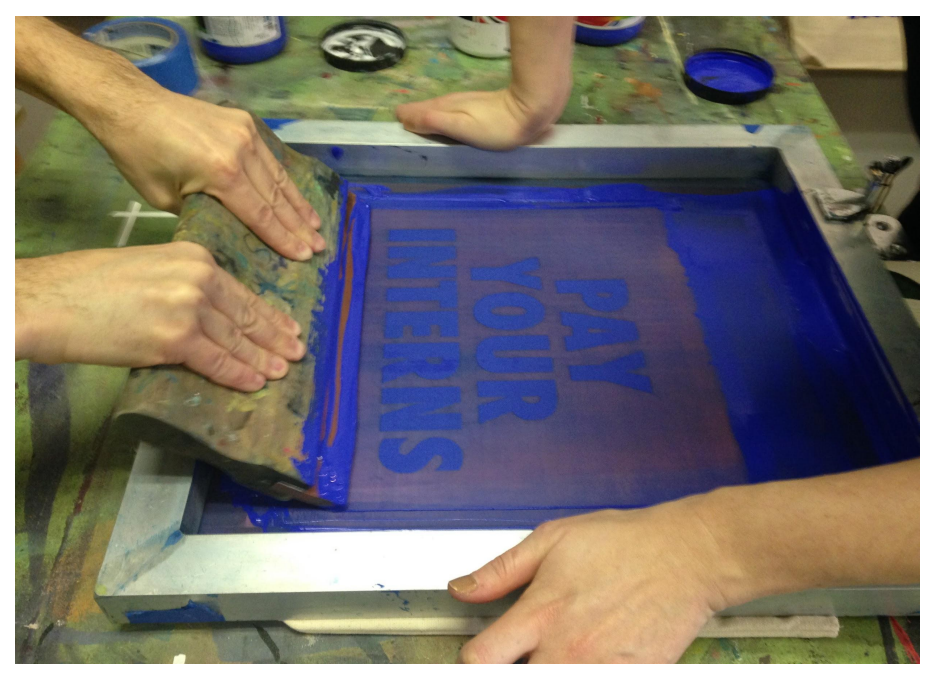

Tote bag screen-printing (Intern Labor Rights)

2013-2014 was a milestone for intern rights, with significant accomplishments in the fight to have interns recognized as employees owed wages and granted rights to new workplace protections. Substantial court decisions, local governments, and corporations in the United States have brought unfair internships to the fore, prompting many employers to change their practices for the better. Several media conglomerates have changed their hiring policies, from terminating their exploitative internship programs to paying their interns. Significant information was released that began to fill in the data gap on unpaid work across the nation. Unpaid and underpaid interns are filing lawsuits against their employees for wage theft. Students are taking matters into their own hands, from demanding that their universities stop posting illegal internships on their job boards to writing theses on the detrimental effect of unpaid internships and free labour. Local governments are beginning to institute policy changes, such as extending sexual harassment and discrimination protections to unpaid interns.

Intern Labor Rights has compiled this report to serve as a resource guide. The report includes a summary of important developments at the legislative and institutional levels; actions and corresponding public responses; links to pivotal articles, panel discussions, and

\footnotetext{
${ }^{1}$ This text is a revised and updated version of an earlier year-end report published on Intern Labor Rights' website.
} 
interviews; an overview of the related struggles in the U.S.; and our most recent activities in 2014.

We welcome feedback and hope to generate further discussion to broaden our point of view. If you are in New York City, Intern Labor Rights meets weekly. For meeting locations and schedules, visit internlaborrights.com, join us on Facebook (facebook.com/internlaborrights), or follow us @InternLabor.

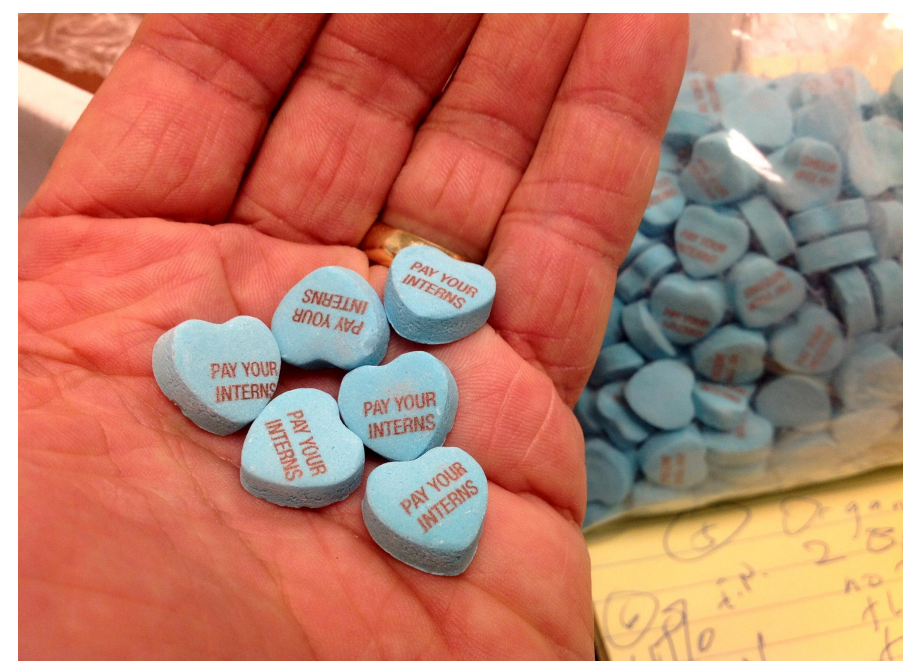

Photo: Intern Labor Rights

\section{History of Intern Labor Rights}

Intern Labor Rights (ILR) has been active since 2012. On February 6, 2012, the Arts \& Labor (2012) working group of Occupy Wall Street published an open letter, "Arts \& Labor \#OWS Call to NYFA: Stop Publishing Classifieds for Unpaid Internships," calling on the New York Foundation of the Arts to "cease posting classified listings for unpaid interns at for-profit institutions on the NYFA website." The letter caught the attention of other activists in New York City dedicated to eliminating the harmful effects of unpaid internships, and dialogue was initiated both in person and online. On March 7, 2012, the first meeting of ILR was held in Brooklyn, New York, when the dedicated group began formulating the long-term, evolving strategy that animates it to this day. Weekly meetings open to anyone interested in contributing to the movement have become one of the signature features of ILR. Since early 2012, ILR continues to grow, attracting participants with varied backgrounds and experiences in the intern economy.

\section{Significant Strides for Interns}

In a landmark judgment in the summer of 2013, a federal court in New York ruled in the case of Glatt v. Fox Searchlight Pictures, Inc. that the plaintiffs' internships did not meet the legal tests under both federal and state law for interns to be considered "trainees" (Greenhouse 2013a). The "interns" were found to be "employees" and therefore owed back pay. The verdict is currently under appeal, but the ruling by Judge William H. Pauley III was explicit, and rejected the suggestion that internships for college credit might somehow be exempt from labour law (United States District Court n.d.). In 2013, we also saw the passage of a crucial bill signed into law by Oregon Governor John Kitzhaber, which extended workplace protections to unpaid interns (Rubin and Stait 2013). Interns are now afforded legal protections from sexual harassment, discrimination, unlawful termination, and other abuses covered under employment law. Similar bills have been passed in New York City and New York State, Washington, D.C., California, and Illinois. Such legislation, however, has stopped shy of the federal court ruling by not actually classifying interns as employees, avoiding the question of 
payment altogether (Hickman and Thompson 2013). Generally, the legislation is limited to banning discrimination and harassment of unpaid interns under the jurisdictions' respective human rights and civil rights laws.

In the context of these legal initiatives, some well-known companies have begun to change their internship policies. In the broadcasting industry, Viacom, the media conglomerate that owns properties including Paramount Pictures, BET, MTV Networks, and Comedy Central, started paying interns in 2013, as did NBC Universal. An AOL article (Gordon 2013) appears to be the sole coverage of many of the changes at major broadcasters, which remain largely under the radar-quite likely because such employers do not wish to draw attention to their prior practices. The AOL article cites an Arizona State University study that claims the Phoenix area saw a 14 percent increase in paid internships in broadcasting and a 20 percent increase in paid publication internships over a one-year period, which represent significant increases.

In August 2013, COO of Facebook and author of the popular book Lean In, Sheryl Sandberg, was scrutinized after an executive of her Lean In Foundation-which encourages women to ask for fair compensation-posted an advertisement for an unpaid editorial internship in New York (Edwards and Smith 2013). Given that unpaid internships are disproportionately held by women (Schwartz 2013), the posting elicited widespread criticism, with Sandberg's foundation ultimately agreeing to offer a formal paid internship program (Kleinman 2013).

The journalism and print media fields saw significant changes. VICE magazine published an article examining the exploited labour of left-leaning media outlets (Davis 2013). Personal narratives and critical analyses of underpaid and unpaid interns exposed unfair labour practices in various liberal news sources, such as Mother Jones, Democracy Now!, and The New Republic. On the day the VICE piece was published, Mother Jones, which had been offering $\$ 1,000$ a month to its interns (approximately $\$ 6$ per hour, or $\$ 4$ below its California home state's minimum wage), announced it would increase its budget for interns and fellows so to pay them $\$ 1,500$ per month. This is slightly above the minimum wage in California. It is worth noting that Mother Jones and other publications may refer to these low-paid, short-term employees as "fellows" rather than "interns," a trend we observe with concern. The Mother Jones fellowships replaced their internship program in 2012, attracting qualified and experienced writers for low pay. VICE itself made use of unpaid interns as late as July 2013, but in the process of preparing its story, brought that practice to an end (Who Pays Interns? n.d. a).

Elsewhere in the media, the political magazine Dissent announced in the Fall of 2013 that its internships would begin paying a $\$ 2,000$ per semester stipend. Gawker Media now runs a minimum wage Editorial Fellowship program (Who Pays Interns? n.d. b). Last summer, Gawker was sued for wage theft by three former unpaid interns (Anonymous 2013). And the online magazine Slate announced a new round of paid internships at the end of 2013, including some positions that had previously been unpaid (Who Pays Interns? n.d. c).

Widely discussed was the decision of Conde Nast-the media company that owns The New Yorker, Vogue, Vanity Fair, Glamour, and other popular magazines (Condé Nast is owned by one of the country's largest privately held companies, Advance Publications) - to suspend its internship program amidst a lawsuit claiming it paid interns less than minimum wage (Maza 2013). Some commentators saw the ending of a prestigious internship program as a loss, but others saw the cessation of an already elitist and exploitative practice as a sign of the beginning of the end for unpaid and underpaid internships (McMorris-Santoro 2013). Others still have speculated that the decision was a cynical and calculated move meant to engender a backlash against interns who step forward to assert their rights-thus "ruining the party" for everyone else-while also minimizing the company's legal exposure. Given the prominent role interns play in the publishing giant's day-to-day operations, however, there's hope that it will lead to a flurry of hiring for paid entry-level positions. When Condé Nast settled the lawsuit in early 2014, it suggested it would now be free to "devote [its] time and resources towards developing meaningful, new opportunities to support up-and-coming talent" (Kelly 2014). Presumably its new program will be paid, both to avoid further lawsuits and to 
remain competitive in the search for talent as other journalism outlets shift to paid internship programs (NYU Journalism, Career Services n.d.).

In a particularly inspiring case, interns at The Nation, the long-running liberal and progressive magazine, successfully fought in 2013 to raise compensation in their internship program, which was increased to match the minimum wage, up from a previous weekly stipend of $\$ 150$ (\$3.75 per hour for a full work week) (Hickman 2013). In their statement, the interns requested a living wage from a magazine that itself plays host to arguments that the current minimum wage for American workers is not high enough (Cockburn 2012). We view this campaign as a step in the right direction, which could potentially inspire more workplace organizing amongst interns around the country. ${ }^{2}$

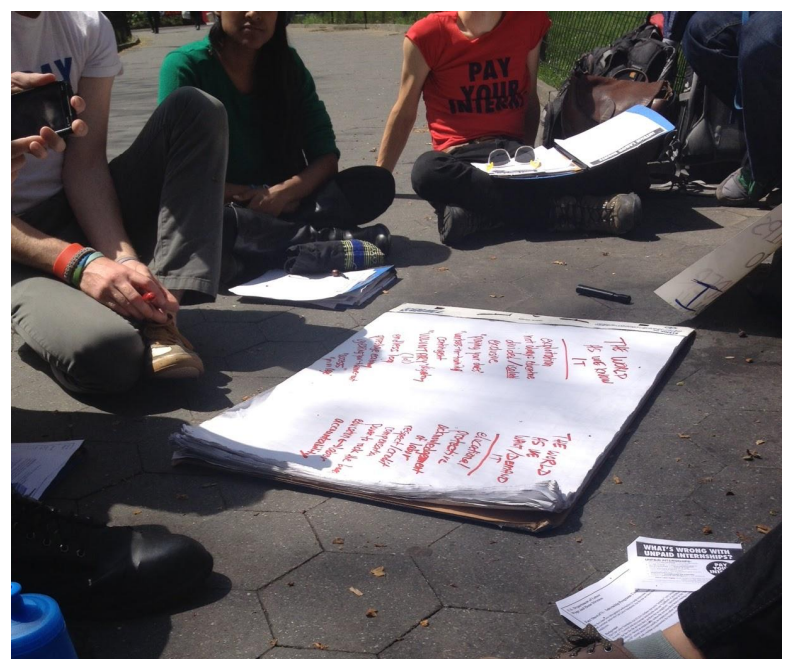

Intern Labor Rights leads the workshop, What Does a Just Internship Look Like? New York, May 2014 (Intern Labor Rights)

\section{Recent Major Advocacy Initiatives}

\subsection{Intern Labor Rights}

ILR members have expanded outreach efforts locally and internationally in the past two years. We were instrumental in the formation of the International Coalition for Fair Internships, a global alliance that came to fruition through a series of virtual global summits beginning in January 2013 (Intern Labor Rights 2014a). We also extended our awareness campaign to various sectors affected by unpaid internships, from fashion to politics. In collaboration with the Student Union of the University of Arts London and Intern Aware, we targeted the Spring 2013 season of Fashion Week in London and New York City, handing out promotional Pay Your Interns "swag bags" to hundreds of Fashion Week attendees (Page 2013; Odell 2013). In summer 2013, we stood in solidarity with unpaid interns at the United Nations, leafleting at the UN's landmark General Assembly and Secretariat building (see unpaidisunfair.org). We also hosted a series of "happy hours" to generate one-on-one conversations that connected activists and organizers with future and past interns in New York City.

In response to the federal court ruling that recognized unpaid interns as employees, we organized a panel discussion in New York in late 2013 that examined the future of internships now that employers will be forced to find new footing on uncertain legal ground. At the panel, Intern Nation author Ross Perlin presented a historical perspective on the formation of the internship and its detrimental effect on our economy; Irma Rodriguez from the Queens

\footnotetext{
2 View the former interns' press release at unpaidlabor.tumblr.com/post/57161802625/press-release-internaction-at-the-nation-leads-to, and our letter of support addressed to the editors of The Nation at internlaborrights.s3.amazonaws.com/wp-content/uploads/2014/02/2013-08-10-Letter-to-The-Nation.pdf.
} 
Community House shared her concerns regarding the widespread phenomenon of unpaid work in activism and its conflict with social and racial justice aims; partner Rachel Bien from Outten \& Golden LLP detailed the legal aspects of intern, volunteer, and worker struggles and rights; and ILR member Dedunu Suraweera addressed the importance of speaking out and organizing. ${ }^{3}$

In Spring 2014, we turned our focus to legislation efforts in New York City and New York State. After 12 years under the contested oversight of Mayor Michael Bloomberg, New York City is moving in a different direction under the progressive-backed leadership of Mayor and former Public Advocate, Bill de Blasio. During the mayoral run, ILR members called for an end to de Blasio's role in proliferating unpaid internships (Schonfeld 2013)-participating in his Reddit AMA (de Blasio 2013), sending letters to his unpaid Organizing Fellowship staff, and speaking with de Blasio during an impromptu campaign meet-and-greet in Greenwich Village. In March, we were invited to make a public statement at the City Council's Civil Rights committee hearing regarding a policy amendment that extends harassment and antidiscrimination protections to unpaid interns (CBS New York 2014). We found the changes to be insufficient, as the manner in which the amendment is phrased excludes many interns from these protections. We reiterated our opinion at the bill-signing ceremony in April (Intern Labor Rights 2014b, 2014c). Also in April, we initiated a campaign calling on Mayor de Blasio to lead by example by instructing New York City's offices and agencies, the companies it contracts, and the organizations engaging city and city-financed resources to cease hiring unpaid interns and begin paying at least minimum wage (Intern Labor Rights 2014d).

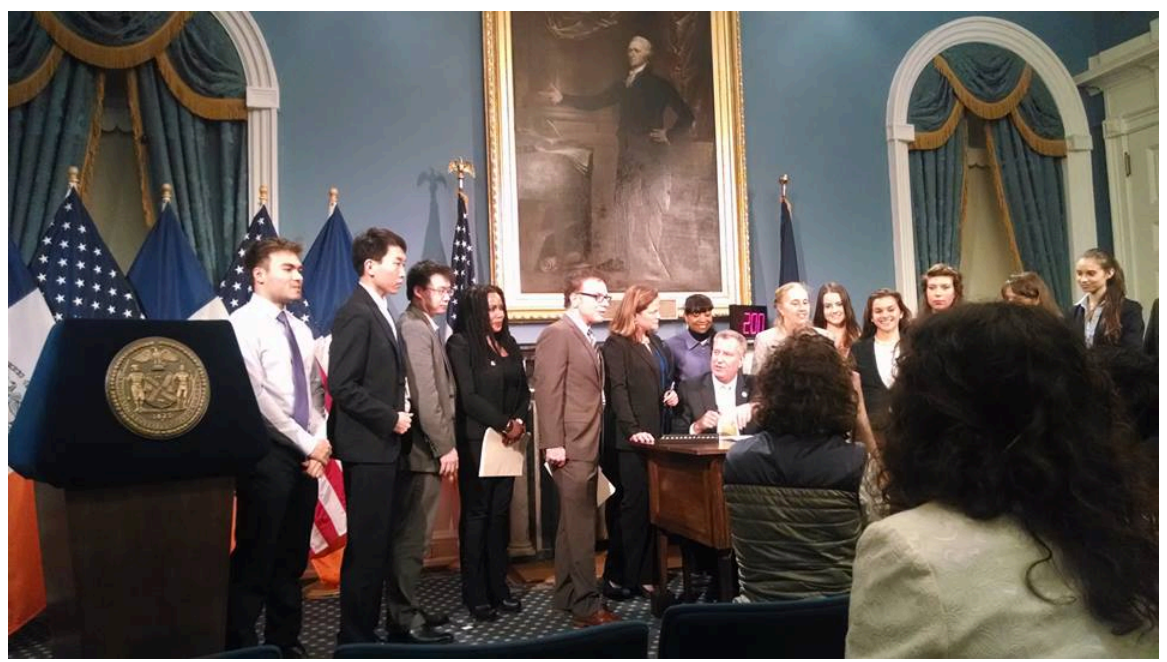

NYC mayor Bill de Blasio signing bill Intro 173-A into law, April 2014 (Intern Labor Rights)

Currently, unpaid interns in the private sector are afforded some avenues to claim back pay (United States Department of Labor 2010). Similar protections for interns in the nonprofit and public sector are, however, less than clear. By advocating for interns to be recognized as employees, ILR hopes the national stage will be set not only for adequate workplace protections, but also for fair wages, greater compliance by employers, and better oversight from educational institutions.

Attendance in our weekly meetings has increased significantly, frequented by not only interns and organizers, but also intern supervisors from publishing, visual art, music, design, and fashion industries. Graduate and undergraduate students have joined us as well to develop their research on unpaid internships, student debt, minimum wage, and workers' rights. Litigators, journalists, and organizers have often served as advisors in these meetings. We continue to hold public workshops and private discussions with individuals wishing to make a

\footnotetext{
${ }^{3}$ Visit internlaborrights.com to watch videos of these presentations.
} 
change in the internship program at their workplace.

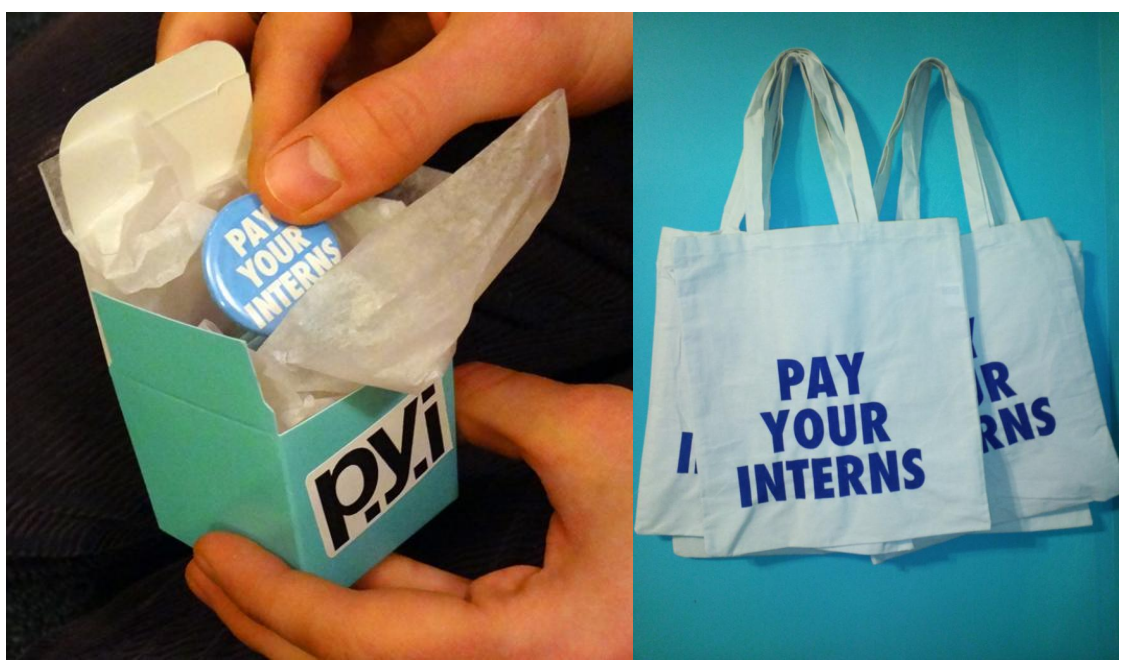

Gift boxes made for Fashion Week 2013 action (L). "Pay Your Interns" Tote Bags (R) (Intern Labor Rights).

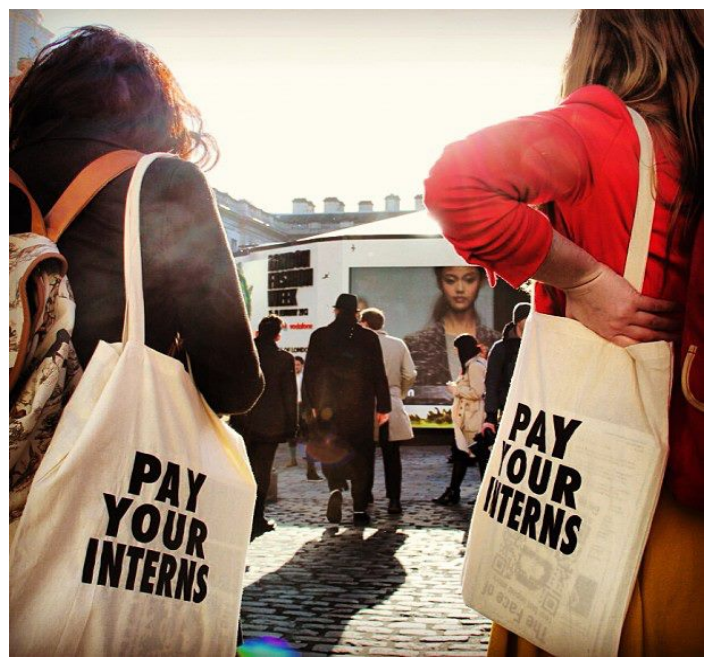

London Fashion Week 2013 (Fairooz Aniqa and Student Union of the University of Arts London)

\subsection{Students Organizing}

In another advocacy development, New York University (NYU) undergraduate Christina Isnardi and several co-organizers ran a petition campaign calling on the school's Career Development office to cease promoting illegal unpaid internships to NYU students. Their effort confronted the paradox that university career offices often overlook labour law violations. This absence of oversight- - defended by university administrations under the claim of satisfying student demand for experiential learning opportunities (Aoun et al. 2010)-harms students' prospects in the long run. The campaign collected over 1,000 signatures and instigated a series of meetings with the petition organizers, the leadership of NYU's career management center, and its general council.

In response, NYU inaugurated several changes:

- An improved screening process has been implemented. All employers must agree that their internship position abides by the Department of Labor guidelines. 
- Although the number of unpaid internships posted on the website have remained steady, there is a stronger emphasis on paid internships and jobs. Samples taken before and after the campaign show that the number of paid internships posted by NYU's career center increased by over 800 percent (from under 500 to over 4,000).

- An internship directory, which lists the Internship Coordinators and Employment Directors at each NYU school, was created to facilitate better oversight of student internships.

- More specific language is being used on the career center website to reduce ambiguous compensation arrangements; instead of only listing whether internships are "Paid" or "Unpaid," now the options listed are "Paid," "Unpaid in compliance with NYU and DOL guidelines," "Both Paid \& Academic Credit," "Academic Credit," and "Stipend."

- To promote greater awareness, NYU has added links providing more detailed information about related labour laws and illegitimate job postings to the career management site.

Despite the above-mentioned plans for reform, NYU continues to post unpaid internships at for-profit companies on its job board.

In early 2014, Columbia University's Dean of Academic Affairs announced that undergraduate colleges have ceased to provide credit for internships. This is a major step forward: the University is no longer encouraging and legitimizing a practice that excludes those who cannot afford to work for free from essential experience in their field (Zhang 2014). This decision followed a series of panels hosted by students on campus, where they raised their issues regarding the University's practice of requiring internships without providing sufficient oversight (Hendrickson 2012).

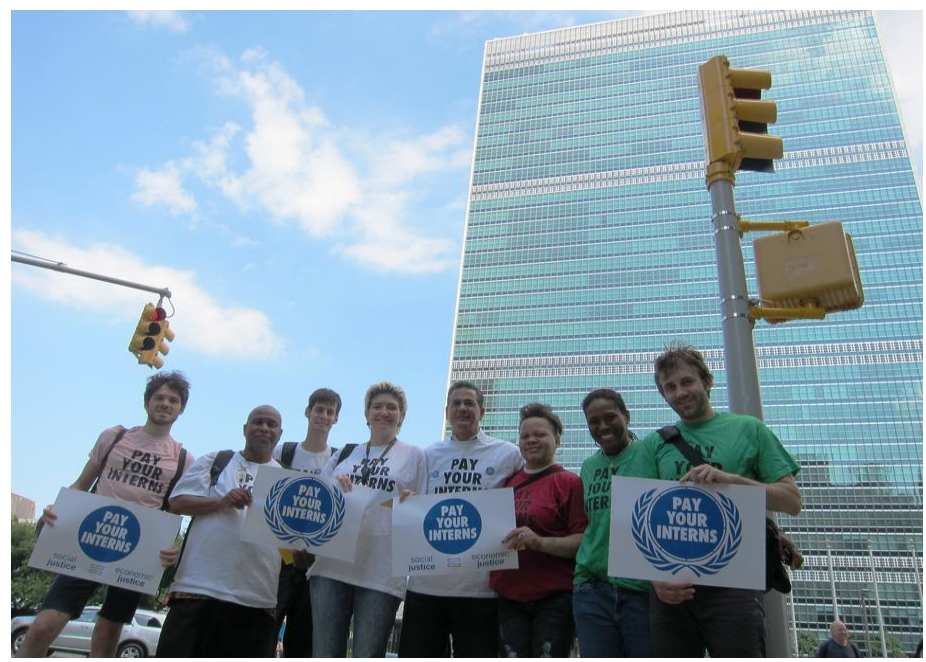

Solidarity protest with United Nations' interns, June 2013 (Intern Labor Rights)

\subsection{ProPublica Series}

To begin filling the data-gap that is endemic to the issue of unpaid internships, in 2013, independent journalism organization ProPublica launched an investigative series on internship programs, which are often conducted without documentation: no personnel records are created or maintained and no income tax withholdings or payroll deductions are made (ProPublica n.d.).

To date, ProPublica has tracked 35 lawsuits that have been filed in the United States 
(Suen and Brandeisky 2014). Some of these lawsuits have been filed in federal court, many on behalf of hundreds, if not thousands, of unpaid interns alleging wage theft.

Before launching its series, ProPublica began a crowdsourcing campaign to fund the research of a paid intern-journalist, Casey McDermott, as she travelled across U.S. campuses collecting stories from interns. The project includes an explanation of applicable laws; appeals for stories from employers and career counselors; a platform for interns-and for those who had to turn down unpaid internships for financial reasons-to share much needed data; an online tool to help calculate the true price of academic internships; a Tumblr page; hashtags to follow the series on Twitter (\#ProjectIntern, \#MyInternStory); and more.

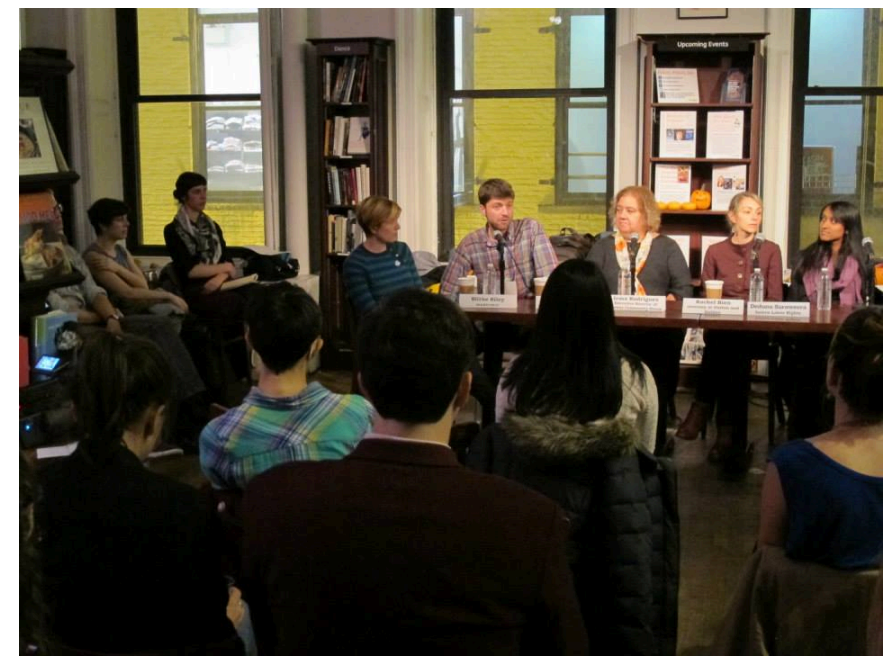

Panel discussion, "Will Work For Free: Breaking Down the Intern Economy," New York, October 2013 (Intern Labor Rights)

\subsection{National Movement}

In 2013-14, issues of income disparity, lack of workplace protections, and the ambiguous value of student labour found overdue attention from the national media. The voices of exploited interns echoed a growing sentiment among unpaid and underpaid workers across academia and the service sector that the current situation is neither just nor sustainable, and that something must be done to turn the tide.

Graduate assistants at New York University voted "overwhelmingly to unionize," making them the only graduate student union currently recognized by a private university in the United States (Greenhouse 2013b). Their affiliation with the United Automobile Workers puts them in a stronger position to negotiate for health benefits and increased stipends in return for the valuable role they play in keeping the University's distinguished academic programs credible and competitive.

Meanwhile, some of the largest revenue generators for universities-student athletesliterally took their message to the field in one of the most high-profile displays of discontent in collegiate sports history. Several college football players marked their armbands with the letters "A.P.U." (All Players United) to call attention to the goals of the National College Players Association (Uthman 2013). Their demands included greater attention to the risks of brain trauma, protecting financial aid for players who have suffered debilitating injuries, and allowing players greater control over how their likeness is used for commercial purposes.

Some of the most important actions in 2013-14 against insufficient wages and precarious working conditions came from workers in the retail and foodservice sectors. Workers from both sectors came out in historic displays of solidarity. On Black Friday in 2013 and 2014, protests erupted in cities across the nation to target Walmart, the flagship among big-box retailers who have capitalized on the fears of both employees and customers, still reeling from the 2008 recession, by keeping wages low (Pilkington 2013). After being given disturb- 
ing financial advice by their employers that encouraged them to sign up for government benefits, fast food workers came out in droves to say, "Can't Survive on \$7.25!" (Picche 2013; Pierson 2013). In September 2014, fast food workers across the U.S. went on their biggest strike yet to demand a raise to $\$ 15$ per hour (Napach 2014). Popular demands for an increase in the minimum wage have been amplified by these low-waged workers, who are organizing to change the system of impoverishment by advocating for fair pay.

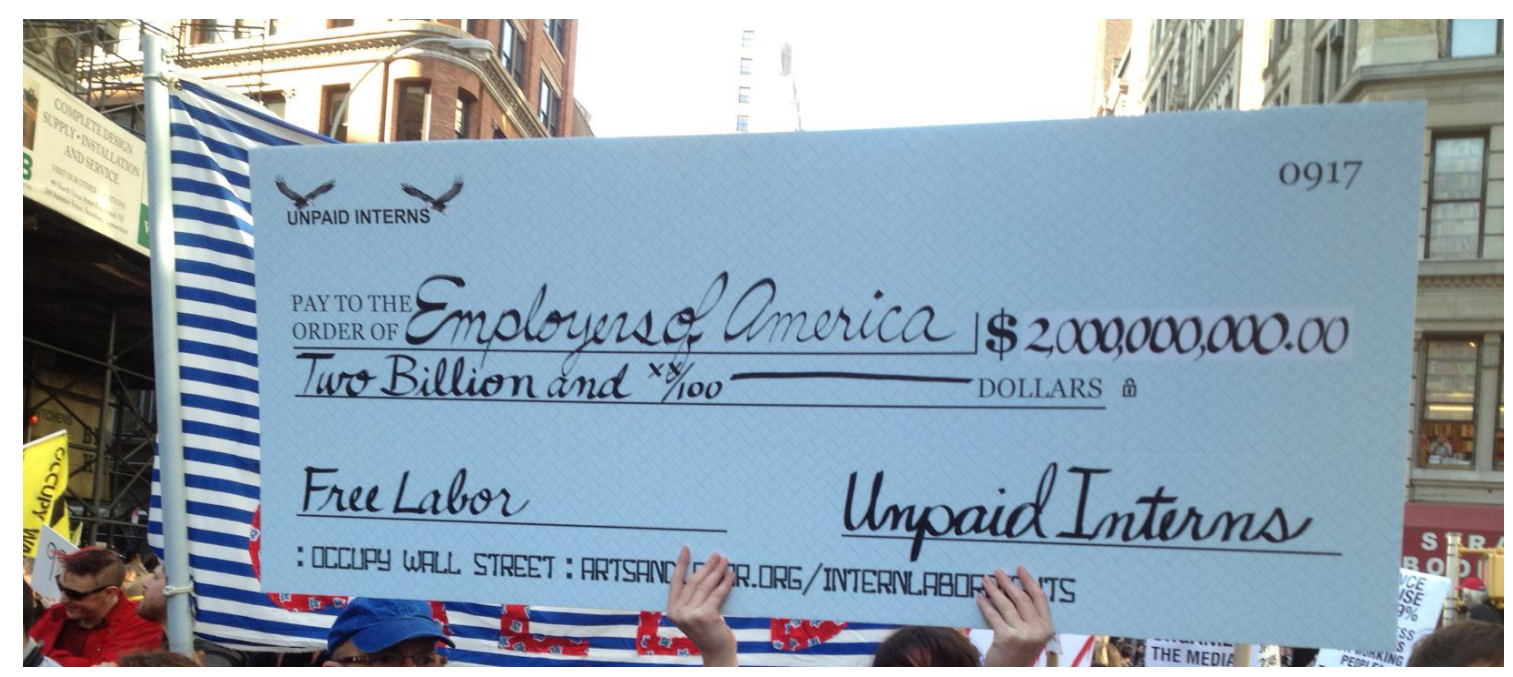

May Day protest, 2012 (Intern Labor Rights)

In September 2014, ILR joined a coalition of labour organizations, led by National Mobilization Against Sweatshops, calling for the New York State Department of Labor and New York Governor Cuomo to enforce existing guidelines to protect workers from wage theft (Intern Labor Rights 2014e).

As all of these campaigns have gained wider recognition and tangible victories in the past year, the intern rights movement sees itself as part of a broader movement to fairly compensate workers who have seen wages and benefits decline steadily in recent decades. We stand in solidarity with these movements as we work together towards a more just and sustainable economic future.

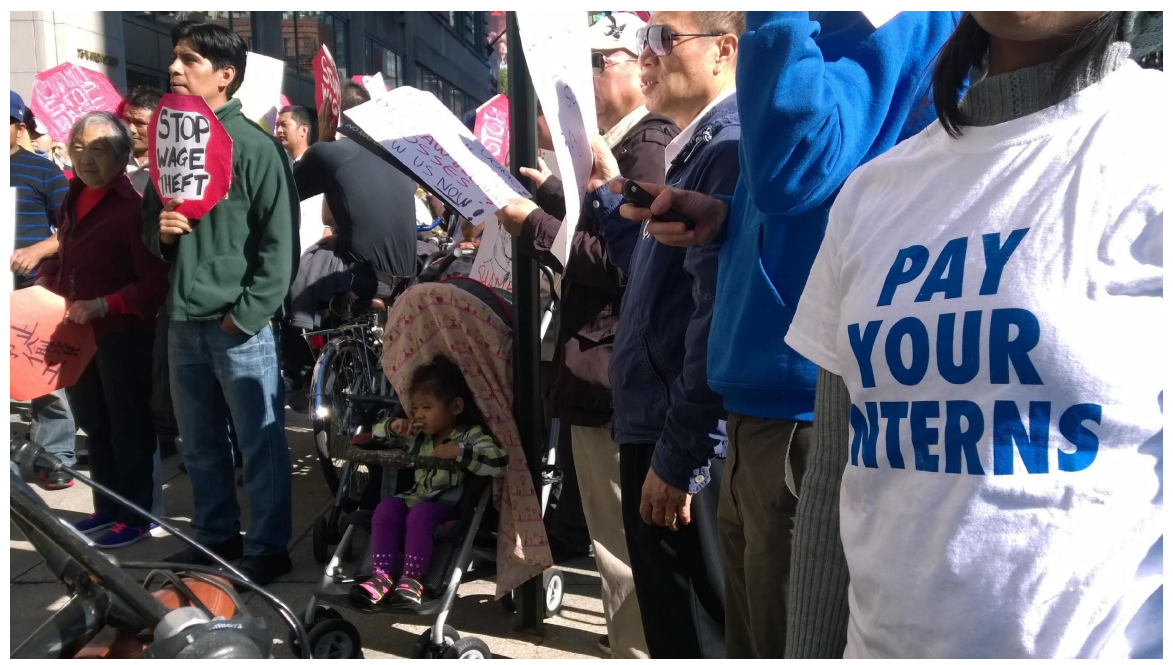

Wage theft rally, New York, September 2014 (Intern Labor Rights) 


\section{Moving Forward}

Despite tremendous victories in and out of the courtrooms, mounting media scrutiny, and an increasingly visible movement against wage theft, the challenges to organizing around internships remain vast. A quick search on almost any online job board will reveal the extent to which employers continue to expect applicants to be willing to offer unpaid labour in exchange for "life experience," "connections," or "professional references." Occasionally these employers even have the audacity to require these uncompensated recruits to have previous experience. This is not surprising, given that high schools are increasingly encouraging their students to take on internships in order to stand out on college applications. This trend prematurely exacerbates the opportunity gap between high- and low-income students, especially for the many students whose families rely on earnings from their part-time employment.

On the legal front, much hinges on the fallout of the July 2015 decision by the U.S. Court of Appeals for the Second Circuit in the Wang v. The Hearst Corporation and Glatt v. Fox Searchlight Pictures cases. The appeals court vacated a lower court's decision that the Fox Searchlight interns were employees owed wages and it articulated new, more employerfriendly standards to evaluate the legal permissibility of unpaid internships under U.S. labor law. At the time of publication, the interns' legal representatives are planning to petition the appeals court for a rehearing. In short, the legal ambiguities surrounding this practice will likely persist for quite some time.

No matter the decision, the need for continued attention to this issue and ongoing advocacy efforts have never been more urgent. Statistics point to record increases in economic inequality and decreases in social mobility. We strongly believe that radical changes to the ethically flawed internship economy can play a significant part in reversing these currents.

\section{References}

Anonymous. 2013. Former Interns Sue Gawker Over No Pay, Allege Media Company Violated Federal Law. Huffington Post. June 22. Accessed March 28, 2015. http://www.huffingtonpost.com/2013/06/22/interns-sue-gawker-unpaid-no-pay_n_3483706.html.

Aoun, Joseph E. et al. 2010. Letter to The Hon. Hilda Hilda L. Solis. Accessed March 28, 2015. http://www.chronicle.com/items/biz/pdf/FINAL US Department of Labor letter.pdf.

Arts \& Labor. 2012. Arts \& Labor \#OWS Call to NYFA: Stop Publishing Classifieds for Unpaid Internships. February 6. Accessed March 28, 2015. http://artsandlabor.org/arts-labor-ows-call-to-nyfastop-publishing-classifieds-for-unpaid-internships/.

CBS New York. 2014. City Council Proposal Would Give Unpaid Interns Right To Sue For Sexual Harassment, Discrimination. CBS New York. March 17. Accessed March 28, 2015. http://www.newyork.cbslocal.com/2014/03/17/city-council-proposal-would-give-unpaid-interns-rightto-sue-for-sexual-harassment-discrimination/.

Cockburn, Alexander. 2012. Why We Must Raise the Minimum Wage. The Nation. April 3. Accessed March 28, 2015. http://www.thenation.com/article/167183/why-we-must-raise-minimum-wage.

Davis, Charles. 2013. The Exploited Laborers of the Liberal Media. VICE. December 2. Accessed March 28, 2015. http://www.vice.com/read/the-exploited-laborers-of-the-liberal-media.

de Blasio, Bill. 2013. I am Bill de Blasio, Democratic Candidate for Mayor of New York City, AMA. Reddit. October 8. http://www.reddit.com.

Edwards, Jim and Kevin Smith. 2013. Sheryl Sandberg's Lean In Foundation is Damaging Her Reputation by Refusing to Pay its Interns. Business Insider. August 15. Accessed March 28, 2015. http://www.businessinsider.com/sheryl-sandbergs-lean-in-foundation-is-damaging-her-reputationby-refusing-to-pay-its-interns-2013-8.

Gordon, Claire. 2013. Media Giants Buckle and Start Paying their Interns. AOL Jobs. June 20. Accessed March 28, 2015. http://www.jobs.aol.com/articles/2013/06/20/media-internships-unpaidlawsuit/.

Greenhouse, Steven. 2013a. Judge Rules that Movie Studio Should Have Been Paying Interns. The New York Times. June 11. Accessed March 28, 2015. http://www.nytimes.com/2013/06/12/business/judge-rules-for-interns-who-sued-foxsearchlight.html? $r=0$.

Greenhouse, Steven. 2013b. N.Y.U. Graduate Assistants to Join Auto Workers' Union. The New York Times. December 12. March 28, 2015. http://www.nytimes.com/2013/12/13/nyregion/nyu-graduateassistants-to-join-auto-workers-union.html? $\quad \mathrm{r}=0$. 
Hendrickson, Zachary. 2012. LectureHop: Internships, Labor Rights, and the Columbia Community. BWOG. November 21. Accessed March 28, 2015. http://www.bwog.com/2012/11/21/lecturehopinternships-labor-rights-and-the-columbia-community/.

Hickman, Blair. 2013. Nation Institute to Pay Interns Minimum Wage. ProPublica. August 2. Accessed March 28, 2015. http://www.propublica.org/article/nation-institute-to-pay-interns-minimum-wage.

Hickman, Blair and Christie Thompson. 2013. How Unpaid Interns Aren't Protected Against Sexual Harassment. ProPublica. August 9. Accessed March 28, 2015. http://www.propublica.org/article/how-unpaid-interns-arent-protected-against-sexual-harassment.

Intern Labor Rights. 2014a. Announcing the Formation of the International Coalition for Fair Internships. January 30. Accessed March 28, 2015. http://www.internlaborrights.com/2014/01/30/announcing-the-formation-of-the-internationalcoalition-for-fair-internships/.

Intern Labor Rights. 2014b. Intern Labor Rights Response to NY City Council Amendment to Protect Interns from Sexual Harrassment. March 27. Accessed March 28, 2015. http://www.internlaborrights.com/2014/03/27/intern-labor-rights-response-to-ny-city-councilamendment-to-protect-interns-from-sexual-harrassment/.

Intern Labor Rights. 2014c. NYC Mayor Bill de Blasio Signs Intern Anti-Discrimination Bill into Law. Intern Labor Rights. April 18. Accessed March 28, 2015. http://www.internlaborrights.com/2014/04/18/nyc-mayor-bill-de-blasio-signs-intern-antidiscrimination-bill-into-law/.

Intern Labor Rights. 2014d. Intern Labor Rights Letter to Mayor de Blasio Regarding Internships in New York City. April 3. Accessed March 28, 2015.

http://www.internlaborrights.com/2014/04/03/intern-labor-rights-letter-to-mayor-de-blasio-regardinginternships-in-new-york-city/.

Intern Labor Rights. 2014e. Governor Cuomo Enforce the Labor Law. September 18. Accessed March 28, 2015. http://www.internlaborrights.com/2014/09/18/governor-cuomo-enforce-the-labor-law/

Kelly, Keith J. 2014. Condé Nast Settles Intern Suit, Hints at New Program. New York Post. April 8. Accessed March 28, 2015. http://www.nypost.com/2014/04/08/conde-nast-settles-intern-suit-hintsat-new-program/.

Kleinman, Alexis. 2013. Sheryl Sandberg's Nonprofit to Start Paid Internship Program After Controversy. Huffington Post. August 16. Accessed March 28, 2015. http://www.huffingtonpost.com/2013/08/16/sheryl-sandberg-interns_n_3767359.html.

Maza, Erik. 2013. Condé Nast Discontinuing Internship Program. Women's Wear Daily. October 23. Accessed May 6, 2015. http://www.wwd.com/media-news/fashion-memopad/internships-ending7242603.

McMorris-Santoro, Evan. 2013. Advocates for Paid Internships Say Condé Nast Just Proved Their Point. BuzzFeed News. October 23. Accessed March 28, 2015.

http://www.buzzfeed.com/evanmcsan/advocates-for-paid-internships-say-conde-nast-just-provedth.

Napach, Bernice. 2014. Fast Food Workers Strike for Higher Pay, Dozens Arrested: "Whatever it Takes." Yahoo! Finance. September 4. Accessed March 28, 2015. http://www.finance.yahoo.com/news/fast-food-workers-stage-their-seventh-one-day-strike--thistime-many-risk-arrest-152933957.html.

NYU Journalism, Career Services. n.d. Fellowship and Paid Internship Programs. Accessed March 28, 2015. http://www.journalism.nyu.edu/career-services/fellowship-and-paid-internship-programs/.

Odell, Amy. 2013. Occupy Movement to Protest Unpaid Internships at Fashion Week. BuzzFeed. Accessed March 28, 2015. http://www.buzzfeed.com/amyodell/protesst-against-unpaid-internships-todescend-on.

Page, Libby. 2013. Push for Paid: A Student Guide to Internships. The Guardian. October 15. Accessed March 28, 2015. http://www.theguardian.com/education/2013/oct/15/student-guide-tointernships.

Picche, Aimee. 2013. McDonald's Blunders with Holiday Tip Advice for Workers. CBS News, Money Watch. December 6. Accessed March 28, 2015. http://www.cbsnews.com/news/mcdonaldsblunders-with-holiday-tip-advice-for-workers/.

Pierson, David. 2013. McDonald's McResources Line Urges Worker to Seek Federal Assistance. LA Times. October 23. Accessed March 28, 2015. http://www.latimes.com/business/money/la-fi-momcdonalds-worker-20131023,0,4084029.story - axzz2if3oFsOr.

Pilkington, Ed. 2013. Black Friday Protests Demand Improved Conditions from Walmart. The Guardian. November 29. Accessed March 28, 2015. http://www.theguardian.com/world/2013/nov/29/black-friday-walmart-protests-wages-jobs. 
ProPublica. n.d. Internships. Accessed March 28, 2015. http://www.propublica.org/series/internships Rubin, Howard and Don Stait. 2013. Oregon Passes Workplace Protection Law for Unpaid Interns. Littler. June 21. Accessed March 28, 2015. http://www.littler.com/publicationpress/publication/oregon-passes-workplace-protection-law-unpaid-interns.

Schonfeld, Zach. 2013. Bill de Blasio Won't Be Paying his Graphic Design Interns. The Wire. September 19. Accessed March 28, 2015. http://www.thewire.com/politics/2013/09/bill-de-blasio-wontbe-paying-his-interns-fall/69636/.

Schwartz, Madeleine. 2013. Opportunity Costs: The True Price of Internships. Dissent. Winter. Accessed March 28, 2015. http://www.dissentmagazine.org/article/opportunity-costs-the-true-price-ofinternships.

Suen, Stephen and Kara Brandeisky. 2014. Tracking Intern Lawsuits. ProPublica. April 14. Accessed March 28, 2015. http://www.projects.propublica.org/graphics/intern-suits.

United States Department of Labor, Wage and Hour Division. 2010. Fact Sheet \#71: Internship Programs Under the Fair Labor Standards Act. April. Accessed March 28, 2015. http://www.dol.gov/whd/regs/compliance/whdfs71.htm.

United States District Court, Southern District New York. n.d. Eric Glatt, et al., against Fox Searchlight Pictures Inc.. Accessed March 28, 2015.

http://www.hollywoodreporter.com/sites/default/files/custom/Documents/fox interns.pdf.

Uthman, Daniel. 2013. College Teams Wear "APU" in Organized Protest of NCAA. USA Today. September 21. Accessed March 28, 2015.

http://www.usatoday.com/story/sports/ncaaf/2013/09/21/college-football-apu-all-players-unitedncpa-ramogi-huma/2847203/.

Who Pays Interns? n.d. a. VICE. Accessed March 28, 2015. http://www.whopaysinterns.tumblr.com/post/68785789118/vice-yes.

Who Pays Interns? n.d. b. Gawker. Accessed March 28, 2015. http://www.whopaysinterns.tumblr.com/post/58807053493/gawker-yes.

Who Pays Interns? n.d. c. Slate. Accessed March 28, 2015. http://www.whopaysinterns.tumblr.com/post/69077040097/slate-yes-finally.

Zhang, Christina. 2014. CSA Announces Changes to Course Withdrawal, Internship Policies. Columbia Spectator. February 21. Accessed March 28, 2015.

http://www.columbiaspectator.com/2014/02/21/csa-announces-changes-course-withdrawalinternship-policies.

\section{About the Author}

Intern Labor Rights

Intern Labor Rights (ILR) is an advocacy group that has been active in the U.S. since early 2012. It grew out of a letter published by Arts \& Labor (originally a working group of Occupy Wall Street) in February 2012 calling on the New York Foundation of the Arts to cease posting classifieds for unpaid interns at for-profit institutions on their online job board. On March 7, 2012, the first ILR meeting was held in Brooklyn, New York, where the dedicated group began formulating the long-term, still-evolving strategy that animates it to this day. ILR continues to grow, attracting to its meetings and actions participants with varied backgrounds and experiences in the intern economy. More information is available at internlaborrights.com. 